The BMJ

kabbasi@bmj.com Follow Kamran on Twitter @KamranAbbasi Cite this as: BMJ2021;374:n1848 http://dx.doi.org/10.1136/bmj.n1848 Published: 22 July 2021

\section{Covid-19: The UK's political gamble that bodes ill for health and the health service}

\section{Kamran Abbasi executive editor}

If you tolerate this, sang the Manic Street Preachers, your children will be next. Are we willing to tolerate the risk of severe illness and long term sequelae of covid-19 in UK children now that only those with severe neurodisabilities, at risk of immunosuppression, or living with an immunosuppressed person are being offered vaccination (doi:10.1136/bmj.n1841) ${ }^{1}$ This decision by the Joint Committee on Vaccination and Immunisation places it and the government under increasing scrutiny. The UK is now an outlier in international vaccination policies.

The UK government is already inviting fear, anger, and lessons in pandemic management from home critics and the international community for its cavalier "freedom day" experiment that risks "recklessly exposing millions of people to the acute and long term effects of mass infection" (https://blogs.bmj.com/bmj/2021/o7/15/governmentsplan-recklessly-exposes-millions-in-the-uk-to-infection-when-they-could-be-vaccinated). ${ }^{2}$

The optimal strategy, argue experts from New Zealand (doi:10.1136/bmj.n1794), is one that pursues elimination-in other words, tolerating only a low level of population infection-until sufficient population vaccination allows society to open up again. ${ }^{3}$ "Countries pursuing an elimination strategy have experienced less disruption and economic damage than those that have focused on mitigation to protect health services," explain David Skegg and Philip Hill.

The UK's gamble is that vaccination levels are already sufficient to lift restrictions now

(doi:10.1136/bmj.n1833). ${ }^{4}$ It's a political gamble that many, including some of the government's own science advisers, are uncomfortable with. The NHS is experiencing winter pressures at the height of summer, and even a small rise in hospital admissions will lengthen the backlog of elective care (https://blogs.bmj.com/bmj/2021/07/13/chris-hopsonnhs-trust-pressures-addressing-demand-when-capacity-is-constrained; doi:10.1136/bmj.n1802). ${ }^{6}$

One option is to do things differently, for example by considering "hot" and "cold" sites for hospital care (doi:10.1136/bmj.n1814). ${ }^{7}$ But there is neither the time nor the workforce capacity to implement radical alternatives-and doing things differently, such as creating a fairer examination and regulatory system for ethnic minority staff (doi:10.1136/bmj.n1725), ${ }^{8}$ is usually limited to empty promises.

The crisis is upon us, exacerbated by freedom day. A "pingdemic" is forcing staff to self-isolate in unprecedented numbers (doi:10.1136/bmj.n1822). ${ }^{9}$ Many of those who can work are burnt out (doi:10.1136/bmj.n1823) ${ }^{10}$; there is no end, no Dr Robotnik big boss finale (doi:10.1136/bmj.n1813). ${ }^{11}$ When staff are under pressure, the virtues of quiet listening, of so much benefit to patients (doi:10.1136/bmj.n1757), ${ }^{12}$ are lost; hope of delivering quality of care that is equitable

(doi:10.1136/bmj.n939), ${ }^{13}$ of levelling up, becomes more distant.

How did we tolerate this? Whichever side of the debate you sit on, for or against restrictions, or somewhere in the middle, how did we allow our health service to be in perpetual crisis and our country to become a high risk experiment in pandemic management? A clue may lie in the politicised and wasteful pursuit of lateral flow tests as a panacea. The available tests generally perform poorly, and if they do have a purpose, such as an early signal of infection in asymptomatic people, their deployment is well beyond their capabilities (doi:10.1136/bmj.n163; doi:10.1136/bmj.n1733). ${ }^{14} 15$

If the experience of lateral flow tests is a warning about the dangers of politically driven health agendas, then that warning must be heeded in the dangers of political control written into the new health and social care bill (doi:10.1136/bmj.n1756; doi:10.1136/bmj.n1767; doi:10.1136/bmj.n1806; doi:10.1136/bmj.n1824). ${ }^{16-19}$ The primary successes of the pandemic have come through delivery of the vaccination programme and rapid research on vaccines and treatments, where data on IL-6 inhibitors offer new hope (doi:10.1136/bmj.m3379). ${ }^{20}$ In these examples, politicians have allowed experts the space to find solutions.

A national health service independent of politicians was an early rallying cry of Fiona Godlee, who announced she will be stepping down after 16 years as editor in chief of The BMJ (doi:10.1136/bmj.n1819). ${ }^{21}$ Under her leadership The BMJ has considerably increased readership and impact and has championed major health challenges such as action on climate change and patient partnership, culminating in her recent accolade as editor of the year in the Association of British Science Writers awards for "vision, creativity, leadership, execution, and impact" during the pandemic. Her quiet listening and fearless intolerance of injustice are virtues that other leaders would do well to emulate.

Mahase E. Covid-19: Vulnerable children aged 12-15 will be offered Pfizer vaccine, UK announces. BMJ 2021;374:n1841doi: 10.1136/bmj.n1841.

2 Pagel C, Drury J, Greenhalgh T, et al. Government's plan recklessly exposes millions in the UK to infection when they could be vaccinated. BMJ Opinion. 15 Jul 2021. https://blogs.bmj.com/bmj/2021/07/15/governments-planrecklessly-exposes-millions-in-the-uk-to-infection-when-they-could-bevaccinated.

3 Skegg DC, Hill PC. Defining covid-19 elimination. BMJ2021;374:n1794. doi: 10.1136/bmj.n1794 pmid: 34266880 
4 Shepherd A. Danse macabre on “freedom day.". BMJ 2021;374:n1833doi: 10.1136/bmj.n1833.

5 Hopson C. NHS Trust pressures-addressing demand when capacity is constrained. BMJ Opinion. 13 Jul 2021. https://blogs.bmj.com/bmi/2021/07/13/chris-hopson-nhs-trust-pressures-addressingdemand-when-capacity-is-constrained.

6 Mahase E. Winter pressure: RSV, flu, and covid-19 could push NHS to breaking point, report warns. BMJ 2021;374:n1802. doi: 10.1136/bmj.n1802 pmid: 34266879

7 Oliver D. David Oliver: Could separating NHS "hot" and "cold" inpatient sites work?BMJ 2021;374:n1814.

8 Esmail A, Everington S. Eradicating ethnic disadvantage in medical education and regulation. BMJ2021;374:n1725. doi: 10.1136/bmj.n1725 pmid: 34257071

9 Rimmer A. Sixty seconds on ... the pingdemic. BMJ 2021;374:n1822. doi: 10.1136/bmj.n1822 pmid: 34281909

10 lacobucci G. Burnout is harming GPs' health and patient care, doctors warn. BM/2021;374:n1823. doi: 10.1136/bmj.n1823 pmid: 34281907

11 Morgan M. Matt Morgan: Medicine, the never ending video game. BMJ 2021;374:n1813doi: 10.1136/bmj.n1813.

12 Covid-19 makes it harder for GPs to offer the quiet listening that made all the difference to me. BMJ2021;374:n1757.

13 Hirschhorn LR, Magge H, Kiflie A. Aiming beyond equality to reach equity: the promise and challenge of quality improvement. BMJ 2021;374:n939doi: 10.1136/bmj.n939.

14 García-Fiñana M, Hughes DM, Cheyne CP, etal. Performance of the Innova SARS-CoV-2 antigen rapid lateral flow test in the Liverpool asymptomatic testing pilot: population based cohort study. BM/2021;374:n1637. doi: 10.1136/bmi.n1637 pmid: 34230058

15 Taylor-Phillips S, Dinnes J. Asymptomatic rapid testing for SARS-CoV-2. BMJ 2021;374:n1733. do: 10.1136/bmi.n1733 pmid: 34233894

16 Edwards N. Political appointees in the NHS: be careful what you wish for. BM/2021;374:n1756 doi: 10.1136/bmj.n1756 pmid: 34253543

17 Alderwick H, Gardner T, Mays N. England's new health and care bill. BMJ2021;374:n1767. doi: 10.1136/bmj.n1767 pmid: 34257143

18 lacobucci G. Health and Care Bill: What changes do healthcare leaders want to see?BMJ 2021;374:n1806. doi: 10.1136/bmj.n1806 pmid: 34266833

19 Salisbury H. Helen Salisbury: Will the latest NHS reorganisation help patients?BMJ 2021;374:n1824doi: 10.1136/bmj.n1824.

20 Rochwerg B, Agarwal A, Siemieniuk RA, etal. A living WHO guideline on drugs for covid-19. BMJ 2020;370:m3379. doi: 10.1136/bmi.m3379 pmid: 32887691

21 Kmietowicz Z. Fiona Godlee to step down as The BM's editor in chief. BMJ 2021;374:n1819. doi: 10.1136/bmi.n1819 pmid: 34281826

This article is made freely available for use in accordance with BMJ's website terms and conditions for the duration of the covid-19 pandemic or until otherwise determined by BMJ. You may use, download and print the article for any lawful, non-commercial purpose (including text and data mining) provided that all copyright notices and trade marks are retained. 